\title{
18 Advanced genetic technologies for improving plant production
}

\author{
Jennifer A. Thomson, Sylvester O. Oikeh, \\ Idah Sithole-Niang and Leena Tripathi
}

\section{Introduction}

Genetically modified (GM) crops have been commercialized since 1996. The rapid adoption of these crops by both large and smallholder farmers in industrial and developing countries reflects their substantial multiple benefits (ISAAA, 2017). Unfortunately, these benefits are not being shared by most African farmers and consumers as only South Africa, Sudan and, very recently, Nigeria, have commercialized GM crops. The main crops are insect tolerant and/or herbicide resistant maize, soybean and cotton. However, African crops suffer from many biotic and abiotic stresses not found elsewhere. Some examples include maize streak virus (MSV), banana Xanthomonas wilt (BXW), cassava mosaic and brown streak viruses and cowpea pod borer insects. In addition, drought is a common phenomenon in many parts of Africa, and it is worsening due to climate change. Standard breeding techniques, including modern improvements such as marker assisted breeding (MAB) have been unable to produce the desired resistant varieties, but many local scientists have succeeded using genetic modification techniques. Some of these will be discussed in this chapter.

\section{State of the art and constraints}

The only countries in Africa which have commercialized GM crops are South Africa, Sudan and Nigeria, the latter in 2018 for cotton and in January 2019 for cowpea. In South Africa, 70 events have been approved since 1998 for food, feed and planting, including 42 maize, 12 soybean, ten cotton, five canola and one rice (ISAAA, 2017). In 2017, the estimated GM maize area was $85 \%$, of which $66 \%$ was stacked insect resistant (IR) and herbicide tolerance (HT), and the rest contained single IR or HT traits in equal proportions. In 2017, 95\% of soybeans planted were HT. All the cotton planted was GM with 95\% stacked and $5 \%$ used for refugia to prevent insects becoming resistant to the IR trait. The IR trait that has been commercialized is due to the expression in the plant of the toxin gene derived from the soil bacterium, Bacillus thuringiensis. Hence, the IR trait is often referred to as Bt. 
Sudan is in its sixth year of commercialization of GM crops, with an estimated 90,000 farmers growing insect resistant cotton in 2017 on farms with an average size of 2.1 hectares (ISAAA, 2017). In 2012, only one variety was planted, but continuous research over the last six years has resulted in the approval of two new hybrids, gradually increasing the acreage from an initial modest launch of 20,000 hectares in 2012, to 192,000 hectares in 2017. The use of GM cotton hybrids has raised yields by two to three times higher than those of conventional varieties.

Burkina Faso commercialized insect resistant cotton for a short period from 2008 to 2016. The reason for the discontinuation of these crops was not a failure of the GM technology but rather that the varieties used had shorter fibre lengths than conventional varieties (ISAAA, 2016). This shows the importance of ensuring that the right varieties of a GM crop are introduced. It is more important to wait for introgression into the best varieties than to forge ahead only to discover later that the wrong varieties were chosen.

While a number of other African countries, such as Kenya, Mozambique, Ethiopia, Ghana, Malawi and Nigeria, are conducting multilocation field trials on a variety of GM crops, none of them has approved commercialization. One of the main reasons that Africa has not accepted GM crops is due to the adverse influence of Europe to this technology. Africa receives most of its aid from Europe, and many Africans study in Europe; therefore, the opinions of Europeans matter to African decision makers. When organizations such as Green Peace, Food Rights Alliance and many more put out statements such as a radio advertisement from the UK-based ActionAid in Uganda, which stated, "Did you know that GMOs can cause cancer and infertility?" (Lynas, 2018), who can blame people from reacting negatively? Even though the ActionAid head office in London later disavowed the advertisement, the damage remained, and local activists are still active in their opposition.

African crops suffer from many biotic and abiotic stresses not found elsewhere. Standard breeding techniques, including modern improvements such as marker assisted breeding (MAB) have been unable to produce resistant varieties, but many local scientists have succeeded using genetic modification techniques. For instance, maize resistant to MSV (Shepherd et al., 2007), bananas resistant to BXW and nematodes (Tripathi et al., 2017), virus resistant cassava (Beyene et al., 2017), pod borer resistant cowpeas (Popelka et al., 2006; Bett et al., 2017; Bosibori et al., 2017) and drought-tolerant and insect-protected maize through the Project Water Efficient Maize for Africa (WEMA; Oikeh et al., 2014; Edge et al., 2018) have all been developed.

However, even though some of these have been field tested in a number of countries, only South Africa has commercialized WEMA products trademarked TELA $^{\circledR}$ maize in 2016 (ISAAA, 2017). As Mark Lynas writes: "[It is] somewhat peculiar that some non-governmental organizations (NGOs), which are ostensibly concerned with poverty reduction, should doggedly oppose such a basic poverty-reducing measure as better seeds for farmers" (Lynas, 2018). These NGOs have led to the development of local equivalents which, together with 
some organic farmers' organizations, are, in our experience, similarly opposed to advances in agricultural biotechnology. In our opinion, at the very least farmers should be allowed to test these crops and make their own decisions.

To give some examples of what African farmers are missing out on, herewith are some of the relevant data from field trials.

\section{Drought-tolerant and insect-protected (TELA $\left.{ }^{\circledR}\right)$ maize through the WEMA Project (now known as the TELA Maize Project)}

Through the Water Efficient Maize for Africa (WEMA) Project (now known as the TELA [TELA is derived from the Latin word tutela which means "protection"] Maize Project), three transgenic traits encoded by the drought-tolerant transgene (DroughtGard ${ }^{\circledR}$, MON87460), the cold-shock protein gene $(C s p B)$ and three $B t$ genes (MON810 (Cry1Ab) and MON89034 (Cry1A.105 and Cry 2Ab2)) were accessed royalty-free for smallholder farmers in Africa by the African Agricultural Technology Foundation (AATF). The Bt genes have been stacked with the DroughtGard ${ }^{\circledR}$ gene to provide several variety options for the farmers who operate in drought-prone environments.

Confined field trials (CFTs) carried out in Kenya and Uganda for five seasons to test the efficacy of the Bt MON810 gene in controlling the spotted stemborer (Chilo partellus) and the African stemborer (Busseola fusca) under conditions of artificial infestation indicated that maize hybrids containing the $B t$ gene yielded, on average, $52 \%$ more than the isogenic hybrids without the gene (Kyetere et al. in press). Similarly, the CFTs carried out with the stacked drought-tolerant and insect-protection (DroughtGard ${ }^{\circledR}+B t$ MON810) traits under natural infestation of the fall armyworm (Spodoptera frugiperda; FAW) and stemborers in Ethiopia, Mozambique and Uganda, and unnatural infestation of FAW and artificial infestation with stemborer larvae in Kenya and Tanzania showed that the Bt MON810 trait gave partial but significant control against the FAW, with full control of stemborers. For example, preliminary results of the trials carried out in Mozambique under natural infestation of both FAW and stemborers, showed that all the transgenic maize hybrids except one realized 21-98\% yield advantage over the non-transgenic isogenic hybrids based on the level of infestation (Figure 18.1).

The FAW is a new insect pest, native to the Americas but recently reported in Africa, where it is ravaging staple crops, particularly maize, causing serious crop destruction with estimated maize yield losses of 8.3-20.6 million tonnes, worth US\$2.48-6.19 billion in 12 African countries (CABI, 2017). It was first reported in Nigeria in 2016, but it has since spread to over 40 countries in Africa, thus posing a major threat to food and nutrition security in Africa.

In South Africa which has a long history of commercializing biotech crops, five TELA ${ }^{\circledR}$ hybrids have been commercialized to smallholder farmers since 2016. Farmers are currently growing these with good protection against stemborer and FAW. 


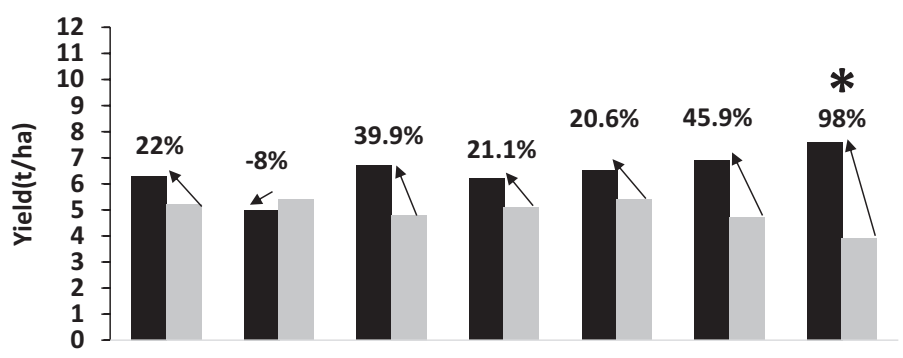

Hybrid 1 Hybrid 2 Hybrid 3 Hybrid 4 Hybrid 5 Hybrid 6 Hybrid 7

- Transgenic Non-transgenic

Figure 18.1 Performance of stacked drought-tolerant and insect-resistant traited hybrids (Bt; red bars) and isogenic hybrids (non-Bt; green bars) under natural infestation of stem borer and FAW in Mozambique, 2017

Source: Own presentation

\section{Bt cowpea}

Cowpea (Vigna unguiculata Walp.) is the most important legume food crop grown in sub-Saharan Africa. Cowpea serves as a major source of dietary protein, being consumed as a fresh leafy vegetable, soft pods as well as grain. In West Africa it is also the main forage crop. Cowpea is drought tolerant and enriches the soil by fixing nitrogen. The major production constraints include a wide range of biotic pests and diseases.

The Network for the Genetic Improvement for Africa, together with the AATF, has been working on cowpea resistant to the pod borer (Maruca vitrata) for a number of years. As mentioned earlier, the AATF obtained the Bt Cry $1 \mathrm{Ab}$ gene from Monsanto, and the transformation of cowpea, variety IT86D-1010, was carried out by Commonwealth Scientific and Industrial Research Organization (CSIRO) in Australia. Event 709A was identified as the lead event. It has a single copy of the Cry $1 \mathrm{Ab}$ gene, which is inherited as a dominant gene giving a segregation ration of $3: 1$. The efficacy of this event was tested in a confined environment under severe artificial infestation of Maruca in Nigeria, Burkina Faso, Ghana and Malawi. It gave near complete control and increased the number of pods per plant by 1.6- to 13-fold and grain yield by several fold.

Event 709A has been backcrossed into farmers' preferred varieties, and, depending on the pressure of Maruca, these out-yielded conventional cowpeas by $20 \%$ to more than $100 \%$. In order to prevent resistance build-up to a single gene, a second $\mathrm{Bt}, \mathrm{Cry} 2 \mathrm{Ab}$, has been used to transform cowpea, and the best six events are undergoing efficacy tests in West Africa.

At the end of January 2019, the Nigerian National Biosafety Management Agency announced the approval for commercial production of $B t$ pod borer resistant cowpea (IITA 2019). A real breakthrough for Africa! 


\section{Banana resistant to banana Xanthomonas wilt}

Banana Xanthomonas wilt (BXW), caused by Xanthomonas campestris pv. musacearum $(\mathrm{Xcm})$, is one of the major diseases of banana that is prevalent in the Great Lakes region of East and Central Africa, where banana is a staple food crop and a source of income for smallholder farmers. There is no known source of resistance within the Musa germplasm except for diploid wild type banana Musa balbisiana. Currently, the control of BXW relies upon improved phytosanitary practices and cultural practices like de-budding, use of clean farming tools and use of pathogen free planting material (Tripathi et al., 2009). These practices can limit the spread of BXW, but the adoption of such practices has been inconsistent, as they are labour intensive.

Use of disease-resistant varieties has been an effective and economically viable strategy for management of plant diseases. In the absence of natural host plant resistance among banana cultivars, researchers have developed transgenic banana expressing the Hypersensitive Response Assisting Protein (Hrap) or Plant Ferredoxin Like Protein (Pflp) gene originated from sweet pepper (Capsicum annиит). These transgenic banana plants have exhibited strong resistance to BXW in the screen house evaluation (Tripathi et al., 2010; Namukwaya et al., 2012). The best 65 resistant lines were further tested in a confined field trial at the National Agricultural Research Laboratory (NARL), Kawanda, Uganda (Tripathi et al., 2014). Twelve transgenic events have been shown to be completely resistant to BXW under confined field trials and also showed flowering and yield (bunch weight and fruit size) characteristics comparable to non-transgenic varieties. The transgenic plants did not exhibit any difference from its non-transformed controls, suggesting that constitutive expression of these genes does not seem to alter plant physiology. To minimize the potential for resistance to a single gene trait, transgenic plants with stacked genes (Hrap$P f(p)$ are being developed for durable high resistance to BXW disease.

\section{Crops developed using CRISPR-type technologies}

All the genetically modified crops mentioned earlier have been produced using Agrobacterium tumefaciens, a naturally occurring soil bacterium, to insert genes into plants. A new technique, however, is now available, called Clustered Regularly Interspaced Short Palindromic Repeats (CRISPR). This is essentially a short piece of RNA which can locate a specific site in a plant's genetic material and, together with an enzyme called Cas9, make a double-stranded cut in the DNA. The plant's own repair mechanism then either repairs it to be the same as before or, for plant improvement use, introduces a few random nucleotides, resulting in a mutation. This is called genome editing and can be used to mutate genes.

A recent article shows how this technique can benefit cassava and banana, staple crops for many Africans (Gomez et al., 2018; Tripathi et al., 2019). Cassava brown streak disease (CBSD) is a major constraint on yields in East and 
Central Africa and threatens its production in West Africa. CBSD is caused by two species of virus which require the interaction of the viral genome-linked protein $(\mathrm{VPg})$ with host translational initiation factor 4E, of which there are five isoforms. By mutating two of these isoforms, cassava plants displayed delayed and attenuated CBSD symptoms, as well as reduced severity and incidence of storage root necrosis. The ability to simultaneously change multiple genes in cassava using CRISPR-Cas9 and achieve these results shows the potential of this technology for Africa.

Banana streak virus (BSV) is a badnavirus of the family Caulimoviridae, affecting production of plantain (Musa spp., AAB genome). Upon infection BSV integrates in the host genome, mainly in the $\mathrm{B}$ genome of banana and is known as endogenous BSV (eBSV). The eBSV gets activated under stress conditions like propagation through tissue culture, hybridization or/and unfavourable environmental conditions such as temperature and water stress. Therefore, BSV is considered as one of the major challenges in plantain breeding and dissemination of hybrids having at least one B genome. Recently, it has been demonstrated that the eBSV sequences integrated in the B genome of plantain can be inactivated by creating targeted mutations in the viral sequences (Tripathi et al., 2019). The CRISPR/Cas9 system editing multiple targets in the integrated virus sequences may serve as a solution of inactivating the eBSV into the infectious virus particles.

By comparison, many crops in current use have been developed by random mutagenesis using either chemicals, such as ethyl methane sulphonate (EMS), 1-methyl-1-nitrosourea and 1-ethyl-1-nitrosourea, or irradiation, such as X-rays, Gamma rays and neutrons. Treatments such as these introduce random mutations throughout the plant's DNA. Breeders will select the trait they are looking for but have no idea what other, potentially harmful, mutations may also reside in these plants (Oladosu et al., 2016). Despite these obvious potential problems, crops developed by random mutagenesis have never required regulation. Food that is commonly consumed that have been developed by these methods include ruby red grapefruit, along with some 3,000 other crop varieties consumed by millions every day, such as mutant wheat used for bread and pasta and barley for beer and whiskey (Kastrinos, 2016).

\section{Government policies}

Laws governing GM crops are in place (or pending) in a number of African countries, but the various committees and authorities tasked with implementing the regulations are, in our experience, often subject to political pressures. Political will is, therefore, essential, but it tends to ebb and flow. The Ethiopian government, for example, was once highly skeptical about biotechnology but recently changed its position, and in 2017, they petitioned to join the WEMA Project to access biotech maize (Getnet, 2018). Various outreach efforts appear to have had a positive influence. In Tanzania, political will is trending in a positive direction, but significant hurdles remain (Abdu, 2019). In Kenya, political 
will to approve the cultivation of GM cotton appears to be growing with the ongoing national variety performance trials (NPTs) that will culminate in variety registration and commercialization (Meeme, 2019). Thus, the approval of Bt cotton for commercialization could create a positive precedent for GM maize approval in the country.

\section{Impacts}

It is estimated that the economic gains from biotech crops for South Africa for the period from 1998 to 2016 was US $\$ 2.3$ billion, with US $\$ 330$ million for 2016 alone (Brookes and Barfoot, 2018). A study focusing on genderaggregated benefits by Gouse et al. (2016) found that female smallholder farmers and household members value GM herbicide tolerant maize higher than their male counterparts because of the labour-saving benefits the technology brings. The researchers found that females in HT maize seed adopting households were able to save ten-12 days of manual weeding per hectare, compared to their conventional and GM insect resistant maize planting and traditional manual weeding counterparts. Interestingly, females spent most of their extra time doing housework (cleaning and cooking) and working in their own or community vegetable gardens.

\section{Conclusion}

It is clear that Africa can gain great benefit from more widespread adoption of GM crops. However, it will require political will from leaders on the continent to allow their own farmers and consumers to participate in growing and using these highly advantageous commodities.

\section{References}

Abdu, F. (2019) GMO research not prohibited in Tanzania - expert. Daily News June 29, 2019. https://www.dailynews.co.tz/news/2019-06-295d1719a911818.aspx.

Bett, B., Gollasch, S., Moore, A., James, W., Armstrong, J., Walsh, T., Harding, R. and Higgins, T.J.V. (2017) Transgenic cowpeas (Vigna unguiculata L. Walp) expressing Bacillus thuringiensis Vip $3 \mathrm{Ba}$ protein are protected against the Maruca pod borer (Maruca vitrata). Plant Cell, Tissue and Organ Culture 131, 335-345.

Beyene, G., Chauhan, R.D., Ilyas, M., Henry Wagaba, H., Claude M. Fauquet, C.M., Douglas Miano, D., Alicai, T. and Taylor, N.J. (2017) A virus-derived stacked RNAi construct confers robust resistance to Cassava Brown Streak Disease. Frontiers in Plant Science 7. doi:103389/pls.2016.02052.

Bosibori, B., Gollasch, S., Moore A., James, W., Armstrong, J., Walsh, T., Harding, R. and Higgins, T.J.V. (2017) Transgenic cowpeas (Vigna unguiculata L. Walp) expressing Bacillus thuringiensis Vip3Ba protein are protected against the Maruca pod borer (Maruca vitrata). Plant Cell Tissue Organ Culture 131,335-345. doi:10.1007/s11240-017-1287-3.

Brookes, G. and Barfoot, P. (2018) Farm income and production impacts of using GM crop technology 1996-2016. GM Crops \& Food 9, 59-89. doi:10.1080/21645698.2018.1464866. 
Centre for Agriculture and Bioscience International - CABI (2017) www.invasive-species. org/fawevidencenote (accessed November 2017).

Edge, M., Oikeh, S.O., Kyetere, D., Mugo, S. and Mashingaidze, K. (2018) Water efficient maize for Africa: A public-private partnership in technology transfer to smallholder farmers in Sub-Saharan Africa. In: Nicholas Kalaitzandonakes, Elias G. Carayannis, Evangelos Grigoroudis and Stelios-Rozakis (eds) From Agriscience to Agribusiness: Theories, Policies and Practices in Technology Transfer and Commercialization. Springer Publication, New York, USA. ISSN 2197-5701 (electronic). 490p.

Getnet, T. (2018) GMO corn test starts in Ethiopia. https://www.capitalethiopia.com/featured/ gmo-corn-test-starts-ethiopia/ (accessed 7 October 2019).

Gomez, M.A., Lin, Z-J.D., Moll, T., Chauhan, R.D., Renninger, K., Beyene, G., Taylor, N.J., Carrington, J.C., Staskawicz, B.J. and Bart, R. (2018) Simultaneous CRISPR/Cas9mediated editing of cassava $e l F 4 E$ isoforms $n C B P-1$ and $n C B P-2$ reduces cassava brown streak disease symptom severity and incidence. Plant Biotechnology Journal 17, 421-434 doi:10.1111/pbi.12987.

Gouse, M., Sengupta, D., Zambrano, P. and Zepeda, J.F. (2016) Genetically modified maize: less drudgery for her, more maize for him? Evidence from smallholder maize farmers in South Africa. World Development 83, 27-38.

IITA (2019) Major breakthrough for farmers and scientists as Nigerian biotech body approves commercial release of genetically modified cowpea. https://www.iita.org/news-item/major-breakthroughfor-farmers-and-scientists-as-nigerian-biotech-body-approves-commercial-release-ofgenetically-modified-cowpea/ (accessed 7 October 2019).

ISAAA (2016) Global status of commercialized biotech/GM crops (2016) ISAAA Brief No. 52. ISAAA, Ithaca, NY.

ISAAA (2017) Global status of commercialized biotech/GM crops in 2017: Biotech crop adoption surges as economic benefits accumulate in 22 years. ISAAA Brief No. 53. ISAAA, Ithaca, NY.

Kastrinos, A. (2016) Delicious mutant foods: Mutagenesis and the genetic modification controversy. Generic Literacy Project, June 13, 2016.

Kyetere, D.T., Okogbenin, E., Okeno, J., Sanni, K.A., Oikeh, S., Munyaradzi, J., Nangayo, F., Kouko, E., Karuiki, A. and Issoufou, A. (In press) The role and contribution of plant breeding and plant biotechnology to sustainable agriculture in Africa. Afrika Focus.

Lynas, M. (2018) Seeds of Science: Why We Got It So Wrong on GMOs. Bloomsbury Sigma, London.

Meeme, V. (2019) Kenya reconsidering GMO crop ban to support food security. Alliance for Science April 30, 2019 https://allianceforscience.cornell.edu/blog/2019/04/kenya-recon sidering-gmo-crop-ban-support-food-security/ (accessed 7 October 2019).

Namukwaya, B., Tripathi, L., Tripathi, J.N., Arinaitwe, G., Mukasa, S.B. and Tushemereirwe W.K. (2012) Transgenic banana expressing PFLP gene confers enhanced resistance to Xanthomonas wilt disease. Transgenic Research 4, 855-865. doi:10.1007/s11248-011-9574-y.

Oikeh, S.O., Nganyamo-Majee, D., Mugo, S.I.N., Mashingaidze, K., Cook, V. and Stephens, M. (2014) Chapter 13: Water efficient maize for Africa: An example of public-private partnership. In: D.D. Songstad, J.L. Hatfield and D.T. Tomes (eds) Biotechnology in Agriculture and Forestry: Convergence of Food Security, Energy Security, and Sustainable Agriculture. Vol. 67, Springer Publication, New York, USA. ISBN 978-3-642-55261-8. 372p.

Oladosu, Y., Rafii, M.Y., Abdullah, N., Hussin, G., Ramli, A., Rahim, H.A., Miah, G. and Usman, M. (2016) Principle and application of plant mutagenesis in crop improvement: A review. Biotechnology and Biotechnological Equipment 30,1-16. https://doi.org/10.1080/ 13102818.1087333 . 
Popelka, J.C., Gollasch, S., Moore, A., Molvig, L. and Higgins, T.J.V. (2006) Genetic transformation of cowpea (Vigna unguiculata L.) and stable transmission of the transgenes to progeny. Plant Cell Reports 25, 304-312.

Shepherd, D.N., Mangwende, T., Martin, D.P., Bezuidenhout, M., Kloppers, F.J., Carolissen, C.H., Monjane, A.L., Rybicki, E.P. and Thomson, J.A. (2007) Maize streak virus-resistant transgenic maize: A first for Africa. Plant Biotechnology Journal 5, 759-767.

Tripathi, J.N., Ntui, V.O., Ron, M., Muiruri, S.K., Britt, A. and Tripathi, L. (2019) CRISPR/Cas9 editing of endogenous banana streak virus in the B genome of Musa spp. overcomes a major challenge in banana breeding. Communications Biology doi:10.1038/ s42003-019-0288-7.

Tripathi, L., Atkinson, H., Roderick, H., Kubiriba, J. and Tripathi, J.N. (2017) Genetically engineered bananas resistant to Xanthomonas wilt disease and nematodes. Food and Energy Security 6, 37-47. doi:10.1002/fes3.101.

Tripathi, L., Mwaka, H., Tripathi, J.N. and Tushemereirwe, W.K. (2010) Expression of sweet pepper Hrap gene in banana enhances resistance to Xanthomonas campestris pv. musacearum. Molecular Plant Pathology 11, 721-731. doi:10.1111/J.1364-3703.2010.00639.X.

Tripathi, L., Mwangi, M., Abele, S., Aritua, V., Tushemereirwe, W.K. and Bandyopadhyay, R. (2009) A threat to banana production in east and central Africa. Plant Disease 93, 440-451. doi:10.1094/PDIS-93-5-0440.

Tripathi, L., Tripathi, J.N., Kiggundu, A., Korie, S., Shotkoski, F. and Tushemereirwe, W.K. (2014) Field trial of Xanthomonas wilt disease-resistant bananas in East Africa. Nature Biotechnology 32 (9), 868-870. doi:10.1038/nbt.3007. 